\title{
Clostridium limosum
}

National Cancer Institute

\section{Source}

National Cancer Institute. Clostridium limosum. NCI Thesaurus. Code C86284.

A species of anaerobic, Gram positive, rod shaped bacteria assigned to the phylum

Firmicutes. This species is lecithinase positive, indole and lipase negative, hydrolyzes

gelatin and does not ferment inositol, glucose or maltose. C. limosum is pathogenic and has been isolated from soil. 